\title{
Arsenic Removal from Drinking Water by Self-Made PMIA Nanofiltration Membrane
}

\author{
Changwei Zhao ${ }^{1 *}$, Songshan Du ${ }^{2,3}$, Tao Wang ${ }^{1}$, Jian Zhang ${ }^{1}$, Zhaokun Luan ${ }^{1}$ \\ ${ }^{1}$ State Key Laboratory of Environmental Aquatic Chemistry, Research Center for Eco-Environmental Sciences, \\ Chinese Academy of Sciences, Beijing, China \\ ${ }^{2}$ Jiangsu Association for Environmental Monitoring, Nanjing, China \\ ${ }^{3}$ Environmental Protection Key Laboratory of Monitoring and Analysis for Organic Pollutions in Surface Water, Nanjing, China \\ Email: ${ }^{*}$ zhaocw@rcees.ac.cn
}

Received May 22, 2012; revised June 21, 2012; accepted June 30, 2012

\begin{abstract}
A self-made PMIA asymmetric nanofiltration membrane was used for arsenic removal from drinking water by NF process. Effects of feed concentration, operating pressure, $\mathrm{pH}$ and existing ions on $\mathrm{As}(\mathrm{V})$ removal were investigated. Experimental results showed that $\mathrm{As}(\mathrm{V})$ rejection was higher than $90 \%$ in the range of investigated As feed concentrations. The $\mathrm{As}(\mathrm{V})$ rejection increased slightly with pressure increase, $\mathrm{As}(\mathrm{V})$ rejection was higher than $90 \%$ in the pressure range of $0.4 \mathrm{MPa}$ to $0.8 \mathrm{MPa}$. $\mathrm{As}(\mathrm{V})$ rejection increased significantly from $83 \%$ at $\mathrm{pH} 3$ to $99 \%$ at $\mathrm{pH} 9$. The presence of $\mathrm{NaCl}$ enhanced $\mathrm{As}(\mathrm{V})$ rejection in the range of feed concentration, and $\mathrm{As}(\mathrm{V})$ rejection can reach up to $99 \%$ at a feed As concentration of $100 \mu \mathrm{g} / \mathrm{L}$, whereas there was a rejection decrease of $8 \%$ in the presence of $\mathrm{Na}_{2} \mathrm{SO}_{4}$ at every feed concentration. The results showed the As(V) detected in the permeate was lower than the EPA recommended MCL up to a feed As concentration of approximately $10 \mu \mathrm{g} / \mathrm{L}$ in the experimental research range.
\end{abstract}

Keywords: Arsenic Removal; Nanofiltration; PMIA; Drinking Water; Rejection

\section{Introduction}

Arsenic is one of several hazardous inorganic species that seriously threaten aquatic environments. Chronic arsenic intake can cause various health effects including skin lesions such as hyperkeratosis and pigmentation changes, circulatory disorders, diabetes and cancers of the bladder, lungs and skin $[1,2]$. Consequently, a new maximum contaminant level (MCL) standard of $10 \mu \mathrm{g} / \mathrm{L}$ arsenic in drinking water recommended by the WHO has been accepted both within the European Union and by the EPA in the USA [3-5].

These new regulations impose a demand for more efficient arsenic removal from drinking water. Among conventional arsenic removal technologies mainly utilizing adsorption and coagulation processes, membrane processes have emerged as a promising new route for high quality water purification. These approaches have many advantages, including no requirement for the addition of chemical substances, easy increase of capacity, separation in the continuous mode and the possibility to easily join membrane processes with other unit processes [6-9]. Arsenic removal pressure-driven membranes are mainly based on reverse osmosis (RO), nanofiltration (NF), ultrafiltration (UF) or microfiltration (MF) [10-12].

"Corresponding author.
Of the available membrane technologies applicable as clean-up methods for drinking water, NF is efficiently able to remove arsenic from water due to the small size of the membrane pores between RO and UF. Because of its advantages, such as low operating pressure and high retention of multivalent anions, it has generated worldwide interest and has been utilized in the removal of various pollutants from drinking-water [13-15]. Recent developments have proved that NF to be a potential technology for arsenic removal from drinking water charging different experimental parameters [16-18].

However, arsenic removal depends on many factors such as membrane properties, feed water composition, $\mathrm{pH}$ and the presence of other co-existent ions. Further investigations changing these parameters are of interest for the development of an arsenic removal strategy utilizing a NF process.

In the present study, a novel self-made PMIA NF membrane was used to remove arsenic by NF. The performance was examined with relation to arsenic rejection under changing operating conditions.

\section{Experimental}

\subsection{Materials}

$\mathrm{Na}_{2} \mathrm{HAsO}_{4} \cdot 7 \mathrm{H}_{2} \mathrm{O}$ salt (Merck 6284) was dissolved in 
deionized water to produce a $1 \mathrm{mg} / \mathrm{L} \mathrm{As}(\mathrm{V})$ stock solution. This stock solution was diluted to prepare $\mathrm{As}(\mathrm{V})$ in the experimental range. $\mathrm{pH}$ was adjusted with either $\mathrm{HCl}$ or $\mathrm{NaOH}$ solution. Poly (m-phenylene isophthalamide) (PMIA) (shown in Figure 1, from Yantai Spandex Co. Ltd. China), N, N'-dimethylacetamide (DMAC), LiCl and acetone (analytical grade, Tianjin Fuchen Chemicals Reagent Factory, China) were used in the preparation of the NF membrane. Different salts $\left(\mathrm{Na}_{2} \mathrm{SO}_{4}, \mathrm{NaCl}\right)$ and other chemicals used in the experiments were all of analytical grade without further purification. A PMIA nanofiltration membrane was self-prepared in our laboratory.

\subsection{NF Membrane Characterization}

The morphology of the PMIA self-made membrane was analyzed using a scanning electron microscope (SEM) (JSM-6301F, JEOL). The samples were cryogenically fractured in liquid nitrogen and sputter-coated with a thin gold film prior to SEM observation.

The zeta potentials of the membrane were determined through electrophoretic mobility measurements in 500 $\mathrm{mg} / \mathrm{L} \mathrm{KCl}$ solution background electrolyte at various $\mathrm{pH}$ values. From the measured electrophoretic mobility, the zeta potential was using calculated $[15,16]$.

\subsection{Arsenic Removal by NF Membrane}

A schematic diagram of the NF experimental setup is shown in Figure 2. The NF membrane module was an annular chamber made of stainless steel in which a membrane supported by porous sintered steel was mounted. The effective area of the membrane was $21.2 \mathrm{~cm}^{2}$. Each new membrane was initially operated for $30 \mathrm{~min}$ at 1.0 MPa before commencing the actual separation study.

The effect of different operating conditions such as

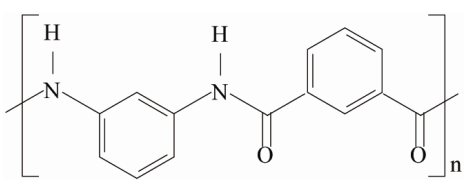

Figure 1. Chemical structure of PMIA.

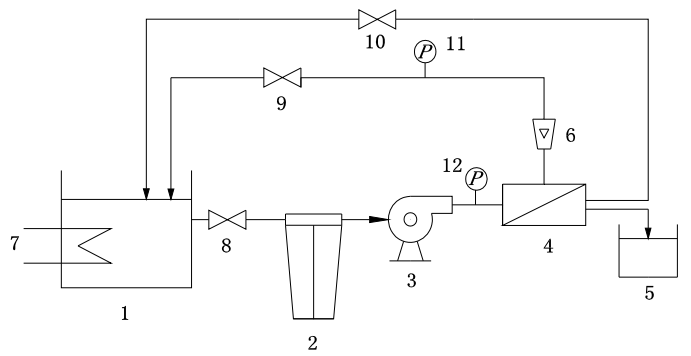

1: feed tank; 2: precision filter; 3: pump; 4: membrane module; $5:$ permeate; 6: flowmeter; 7: heater; 8,9 and 10: valve; 11 and 12: pressure gauge.

Figure 2. Schematic diagram of the experimental setup. membrane properties, As feed concentration, operating pressure, $\mathrm{pH}$ and co-existent ions on As rejection was investigated in experimental trials. Each experiment was repeated at least three times to obtain the results presented in this study, with results averaged with a variation of $\pm 5 \%$.

The rejection $R$, defined as:

$$
R=1-\frac{C_{p}}{C_{f}}
$$

with $C_{p}$ and $C_{f}$ as permeate and feed concentration, respectively, was determined in each experiment.

\subsection{Sample Analyses}

The arsenic concentration was analyzed on an atomic fluorescence spectrometer (AF-610A, Rayleigh Analytical Instrument Co., China). In order to determine reproducibility of results, each group of experiments was repeated. The experiments were performed in duplicate and mean values considered. The blank controls showed no detectable arsenic or iron adsorbed onto the flask walls. The $\mathrm{pH}$ value of the solutions was measured with a $\mathrm{pH}$ meter (FE20, Mettler Toledo).

\section{Results and Discussions}

\subsection{NF Membrane Structure and Performance}

The SEM morphology of our self-made membrane is shown in Figure 3. From Figure 3(a), we can see that surface of the self-made NF membrane has a dense and tight structure. From Figure 3(b) of the cross-section of the NF membrane, we can see that the originally porous surface of substrate is covered by a flat featureless PMIA layer.

The zeta potential of the membrane as a function of $\mathrm{pH}$ is shown in Figure 4. The self-made membrane was always negative within the experimental $\mathrm{pH}$ ranges from 3 to 9 . In general, the membrane became more negative with increasing $\mathrm{pH}$.

\subsection{Effect of Arsenic Concentration on Arsenic Removal}

Figure 5 shows the effect of As feed concentration on $\mathrm{As}(\mathrm{V})$ rejection for $\mathrm{NF}$ membrane at $25^{\circ} \mathrm{C}$ and $0.5 \mathrm{MPa}$. $\mathrm{As}(\mathrm{V})$ rejection was higher than $90 \%$ in the range of investigated As feed concentrations. As concentration in the permeate increased with increasing feed As concentration. As detected in the permeate was lower than the EPA-recommended MCL up to a feed As concentration of about $10 \mu \mathrm{g} / \mathrm{L}$.

\subsection{Effect of Operating Pressure on Arsenic Removal}

In order to examine the influence of operating pressure 


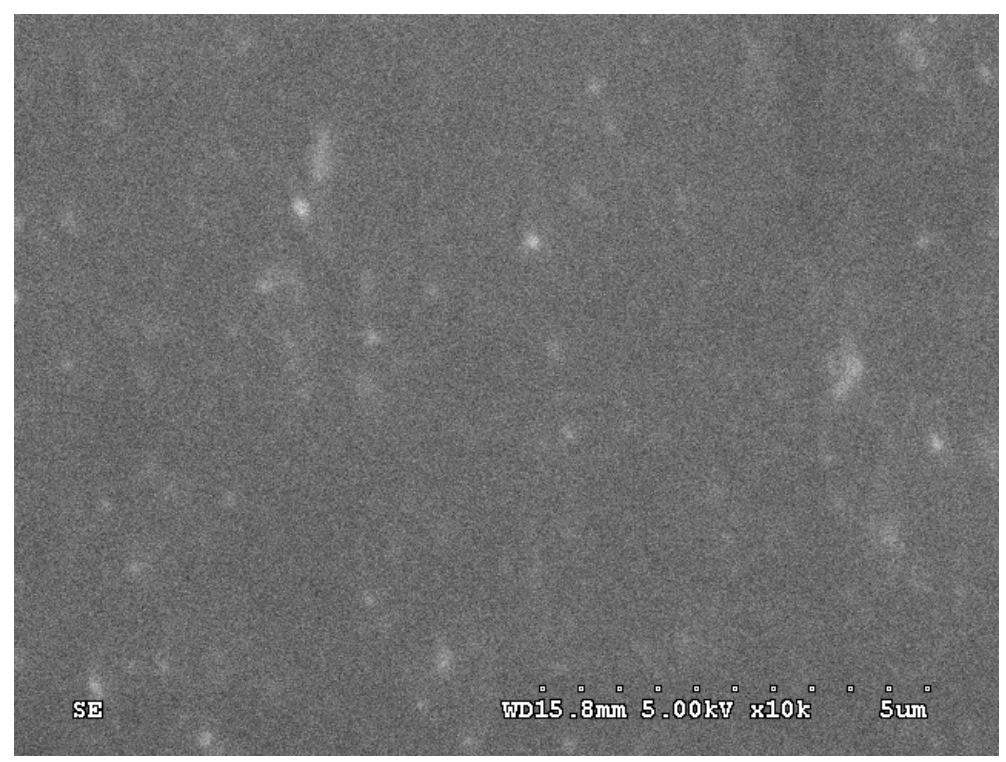

(a)

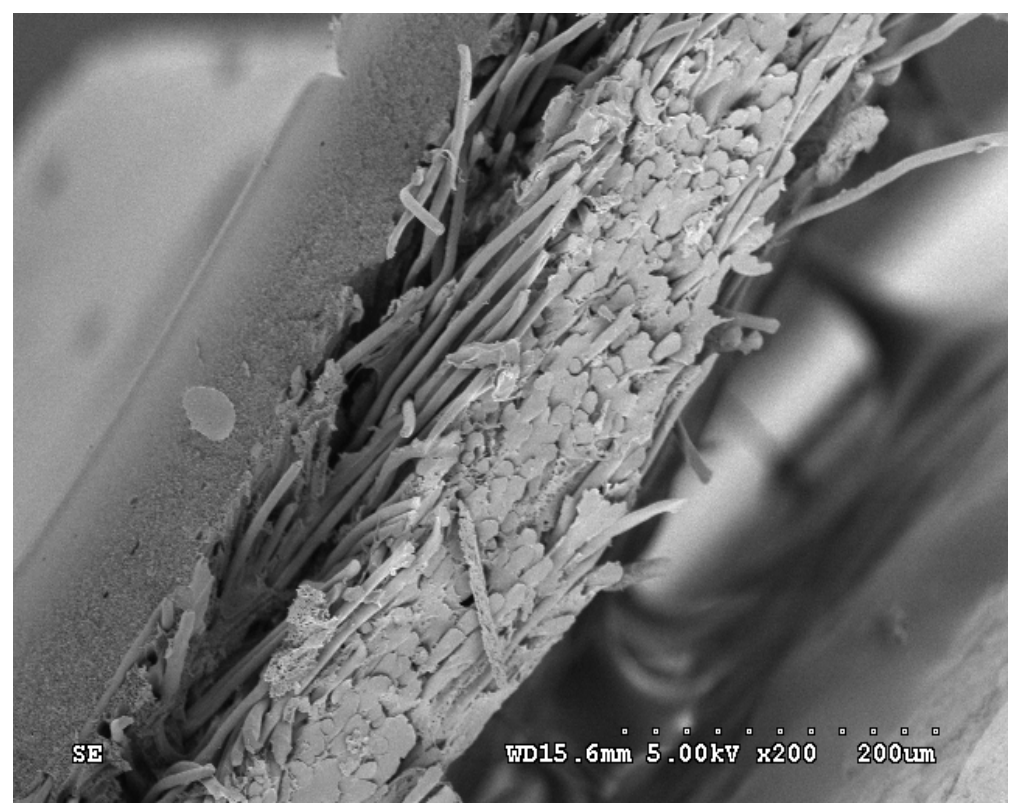

(b)

Figure 3. SEM photographs of the self-made membrane (a) Surface 10,000×; (b) Cross-section $2000 \times$.

on the removal of arsenic species, experiments were investigated at a feed As concentration of $60 \mu \mathrm{g} / \mathrm{L}$ at $25^{\circ} \mathrm{C}$ and $\mathrm{pH}=7$, results are shown in Figure 6. It can be seen that $\mathrm{As}(\mathrm{V})$ rejection was higher than $90 \%$ over the pressure range investigated. In general, arsenic removal efficiency increased slightly with increasing pressure. This can be attributed to an increase in permeate flux with increasing pressure, resulting in lower arsenic concentration in the permeate and subsequently improving $\mathrm{As}(\mathrm{V})$ rejection $[9,19]$.

The concentration of $\mathrm{As}(\mathrm{V})$ in the permeate decreased with increasing pressure. The amount of As detected in the permeate was lower than the EPA recommended MCL up to a feed As concentration of about $10 \mu \mathrm{g} / \mathrm{L}$ over the pressure range investigated.

\subsection{Effect of $\mathrm{pH}$ on Arsenic Removal}

Removal of arsenic by NF membrane is influenced by membrane surface charge (represented by the zeta potential) [9]. $\mathrm{pH}$ is one of the most important parameters controlling As(V) species from water body. For pentavalent arsenic in a $\mathrm{pH}$ range of $2.0-7.0$, the corresponding sta-

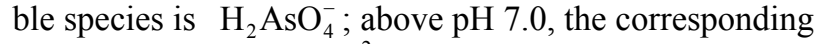
stable species is $\mathrm{HAsO}_{4}^{2-}$ [14]. To examine the influ- 


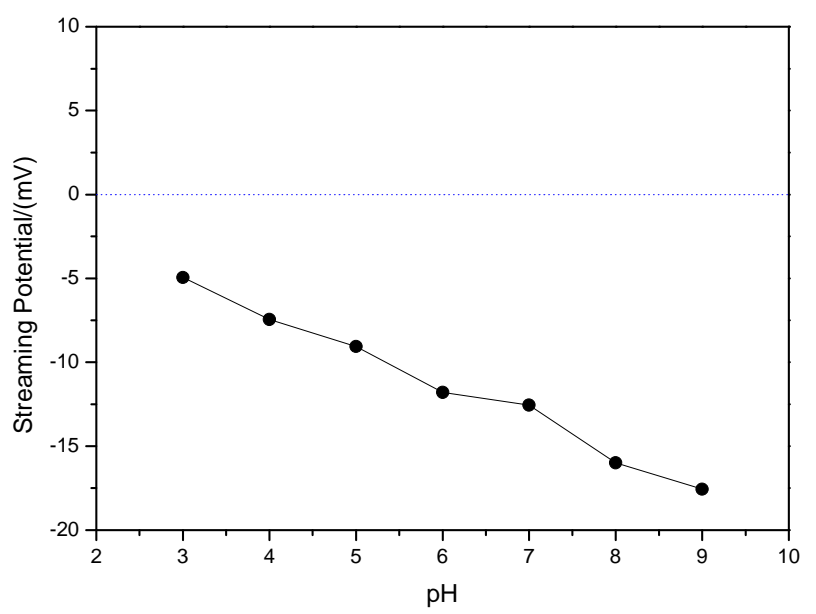

Figure 4. Streaming potential of membrane at different $\mathrm{pH}$.

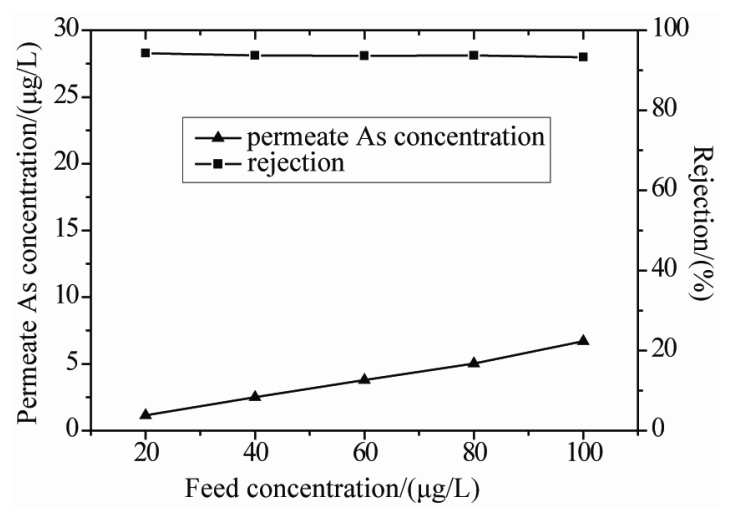

Figure 5. Effect of As feed concentration on the removal of $\operatorname{As}(\mathrm{V})$ (temperature $=25^{\circ} \mathrm{C}, \mathrm{pH}=7$, pressure $\left.=0.5 \mathrm{MPa}\right)$.

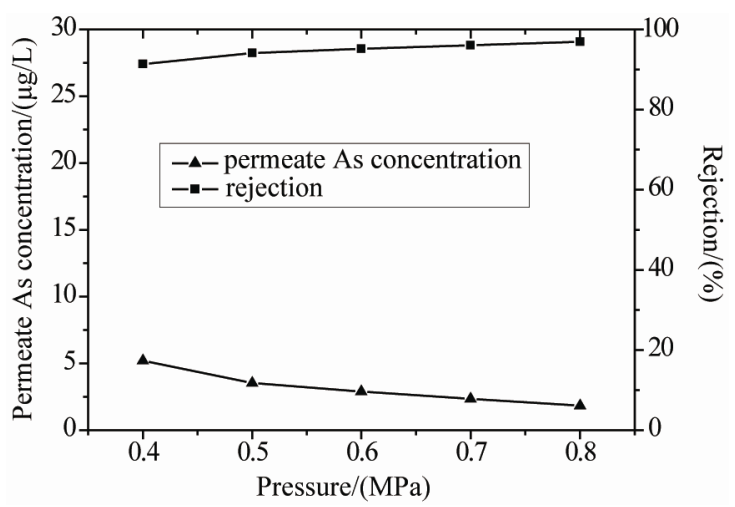

Figure 6. Effect of operating pressure on the removal of $\operatorname{As}(V)\left(\right.$ feed concentration $=60 \mu \mathrm{g} / \mathrm{L}$, temperature $=25^{\circ} \mathrm{C}$, pH = 7).

ence of $\mathrm{pH}$ on the removal of arsenic species, experiments were investigated in a $\mathrm{pH}$ range 3 to 11 at a feed As concentration of $60 \mu \mathrm{g} / \mathrm{L}, 25^{\circ} \mathrm{C}$ and $0.5 \mathrm{MPa}$, and results are shown in Figure 7.

It can be seen that $\mathrm{As}(\mathrm{V})$ rejection increased significantly with increasing $\mathrm{pH}$. Specifically, $\mathrm{As}(\mathrm{V})$ rejection

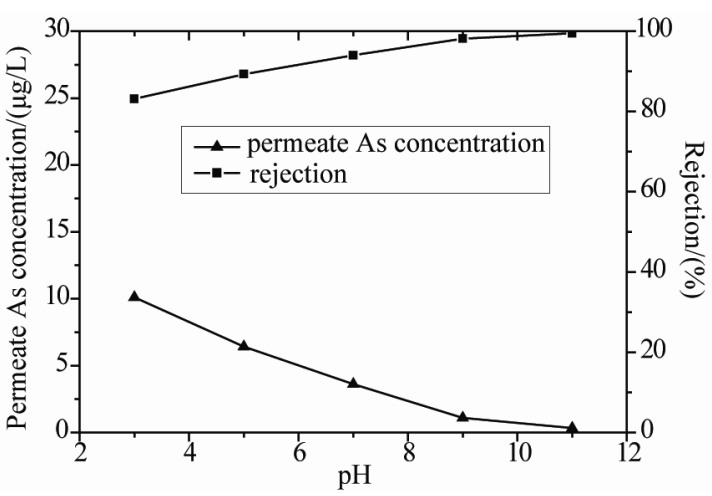

Figure 7. Effect of the pH on the removal of $\operatorname{As}(\mathrm{V})$ (feed concentration $=60 \mu \mathrm{g} / \mathrm{L}$, temperature $=25^{\circ} \mathrm{C}$, pressure $=0.5$ MPa).

increased from $83 \%$ at $\mathrm{pH} 3$ to $99 \%$ at $\mathrm{pH} 9$. The increase in $\mathrm{As}(\mathrm{V})$ rejection at higher $\mathrm{pH}$ can be attributed to the two factors. Firstly, the magnitude of electric repulsion on divalent $\mathrm{As}(\mathrm{V})$ would be higher than that on monovalent $\mathrm{As}(\mathrm{V})$; the monovalent ion $\left(\mathrm{H}_{2} \mathrm{AsO}_{4}^{-}\right)$is dominant in a $\mathrm{pH}$ range of $3-6$ whist the divalent ion $\left(\mathrm{HAsO}_{4}^{2-}\right)$ is dominant above $\mathrm{pH}$ 7. Divalent ions are rejected at a much higher rate compared to monovalent ones due to the larger hydrated radii of divalent ions. Secondly, the membrane charge density in terms of zeta potential decreases with $\mathrm{pH}$ increase; membrane becomes more negative as $\mathrm{pH}$ increases, increasing the effect of charge exclusion in rejection. This is consistent with the previous observation that NF membranes exhibit a typical Donnan exclusion behavior and charge interaction charge the separation of negative solutes $[20,21]$. This result indicates that $\mathrm{pH}$ has a significant influence on $\mathrm{As}(\mathrm{V})$ removal due to arsenic speciation with variation in $\mathrm{pH}[15,22]$.

The concentration of $\mathrm{As}(\mathrm{V})$ in the permeate decreased in the range of the investigated $\mathrm{pH}$. As detected in the permeate was below than the EPA recommended MCL up to a feed As concentration of about $10 \mu \mathrm{g} / \mathrm{L}$. For membrane the highest arsenic removal corresponds to the lowest arsenic concentration in permeate occurred at higher $\mathrm{pH}$.

\subsection{Effect of Other Ions on Arsenic Removal}

Various inorganic substances exist in natural waters, and the presence of these substances can interfere with arsenic removal, so it is important to interpret the rejection characteristics of arsenic species in a mixed salt solution using a NF process. $\mathrm{NaCl}$ and $\mathrm{Na}_{2} \mathrm{SO}_{4}$ were selected to assess the effects of co-existing anions on arsenic removal.

Figure 8 shows the removal of As from DI water, 10 $\mathrm{mN} \mathrm{NaCl}$ and $10 \mathrm{mN} \mathrm{Na}_{2} \mathrm{SO}_{4}$ solutions at $\mathrm{pH} 7$ by our self-made membrane. Consistent with Donnan exclusion, 


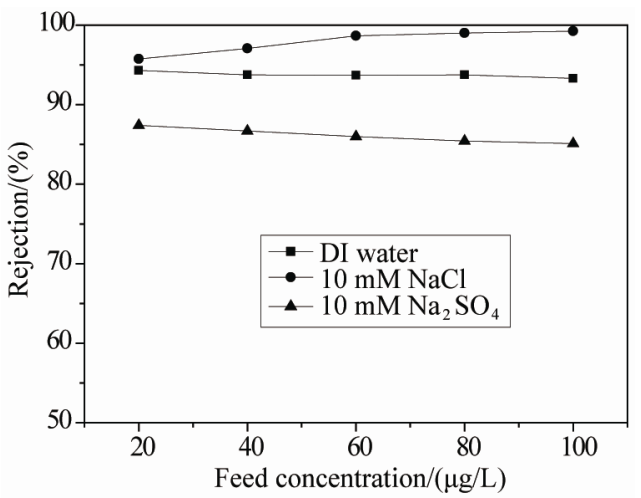

Figure 8. Removal of $\mathrm{As}(\mathrm{V})$ from DI water, $10 \mathrm{mN} \mathrm{NaCl}$ and $10 \mathrm{mN} \mathrm{Na} \mathrm{SO}_{4}$ solutions as a function of $\mathrm{As}(\mathrm{V})$ concentration (temperature $=25^{\circ} \mathrm{C}, \mathrm{pH}=7$, pressure $=0.5 \mathrm{MPa}$ ).

$\mathrm{HAsO}_{4}^{2-}$ removal from DI water decreased slightly with increasing initial feed concentration. The presence of $\mathrm{NaCl}$ enhanced $\mathrm{As}(\mathrm{V})$ rejection in the range of feed concentration, and $\mathrm{As}(\mathrm{V})$ rejection can reach up to $99 \%$ at a feed As concentration of $100 \mu \mathrm{g} / \mathrm{L}$, whereas there was a rejection decrease of $8 \%$ in the presence of $\mathrm{Na}_{2} \mathrm{SO}_{4}$ at every feed concentration. This may be attributed to the preferential passage phenomenon of more mobile co-ions. When the solution's $\mathrm{pH}$ is 7, the $\mathrm{As}(\mathrm{V})$ exists as $\mathrm{HAsO}_{4}^{2-}$. This phenomenon was also observed in earlier studies $[23,24]$. However, due to prove the predominance of the Donnan potential over a steric effect (i.e. $\mathrm{SO}_{4}^{2-}$ is rejected at a higher rate than $\mathrm{HAsO}_{4}^{2-}$ regardless of their diffusivity order), $\mathrm{As}(\mathrm{V})$ rejection decreased in the presence of $\mathrm{SO}_{4}^{2-}$.

\section{Conclusion}

A self-made PMIA asymmetric nanofiltration membrane was used for removal of arsenic from drinking water. It was found that the main operating conditions of feed concentration, operating pressure, $\mathrm{pH}$ and co-existent ions impacted on $\mathrm{As}(\mathrm{V})$ removal efficiency. The change of feed arsenic concentration had little effect on $\mathrm{As}(\mathrm{V})$ removal. As $(\mathrm{V})$ rejection was higher than $90 \%$ in the range of investigated As feed concentrations. As detected in the permeate was lower than the EPA recommended MCL up to a feed As concentration of about $10 \mu \mathrm{g} / \mathrm{L}$. The $\mathrm{As}(\mathrm{V})$ rejection increased slightly with increasing pressure, rejection was higher than $90 \%$ over the investigated pressure range. $\mathrm{pH}$ change had a significant effect on $\mathrm{As}(\mathrm{V})$ removal; $\mathrm{As}(\mathrm{V})$ rejection increased from $83 \%$ at $\mathrm{pH} 3$ to $99 \%$ above $\mathrm{pH} 9$. Various inorganic substances had significant effects on As(V) removal. The presence of $\mathrm{NaCl}$ enhanced $\mathrm{As}(\mathrm{V})$ rejection in the range of feed concentration, and $\mathrm{As}(\mathrm{V})$ rejection reached up to $99 \%$ at a feed As concentration of $100 \mu \mathrm{g} / \mathrm{L}$. There was a rejection decrease of $8 \%$ in the presence of $\mathrm{Na}_{2} \mathrm{SO}_{4}$ at every feed concentration. $\mathrm{As}(\mathrm{V})$ detected in the permeate was lower than the EPA recommended MCL up to a feed As concentration of around $10 \mu \mathrm{g} / \mathrm{L}$ in the experimental range.

\section{Acknowledgements}

The financial support provided by the National High Technology R \& D Program (863) from Ministry of Science \& Technology of China (Grant No. 2007AA06Z339, 2009AA062901, 2008AA06A414), and National Natural Science Foundation of China (No. 50978245, 21176245, 21076219 ) is gratefully acknowledged by the authors.

\section{REFERENCES}

[1] T. Viraraghavan, et al., "Arsenic in Drinking WaterProblems and Solutions," Water Science and Technology, Vol. 40, No. 2, 1999, pp. 69-76. doi:10.1016/S0273-1223(99)00432-1

[2] A. Figoli, et al., "Influence of Operating Parameters on the Arsenic Removal by Nanofitration," Water Research, Vol. 44, No. 1, 2010, pp. 97-104.

[3] R. S. Harisha, et al., "Arsenic Removal from Drinking Water Using Thin Film Composite Nanofiltration Membrane," Desalination, Vol. 252, No. 1-3, 2010, pp. 75-80. doi:10.1016/j.desal.2009.10.022

[4] European Commission Directive 98/83/EC, "Related with Drinking Water Quality Intended for Human Consumption," Brussels, 1998.

[5] M. J. Haron, et al., "Sorption Removal of Arsenic by Cerium-Exchanged Zeolite P," Materials Science and Engineering B, Vol. 149, No. 2, 2008, pp. 204-208. doi:10.1016/j.mseb.2007.11.028

[6] M. A. Paul and R. L. Douglas, "Anisotropic Flat Sheet Membrane Formation via TIPS: Thermal Effects," Journal of Membrane Science, Vol. 171, No. 1, 2000, pp. 1-18. doi:10.1016/S0376-7388(99)00376-2

[7] C. M. Iesan, et al., "Evaluation of a Novel Hybrid Inogranic/Organic Polymer Type Material in the Arsenic Removal Process Form Drinking Water," Water Research, Vol. 42, No. 16, 2008, pp. 4327-4333. doi:10.1016/j.watres.2008.06.011

[8] A. Oehmen, et al., "Arsenic Removal from Drinking Water through a Hybrid Ion Exchange Membrane-Coagulation Process," Separation and Purification Technology, Vol. 83, No. 15, 2011, pp. 137-143. doi:10.1016/j.seppur.2011.09.027

[9] S. Ahmed, et al., "Performance of Nanofiltration Membrane in a Vibrating Module (VSEP-NF) for Arsenic Removal," Desalination, Vol. 252, No. 1-3, 2010, pp. 127-134. doi:10.1016/i.desal.2009.10.013

[10] M. C. Shih, "An Overview of Arsenic Removal by Pressure-Driven Membrane Processes," Desalination, Vol. 172, No. 1, 2005, pp. 85-97. doi:10.1016/j.desal.2004.07.031

[11] T. Urase, et al., "Effect of pH on Rejection of Different Species of Arsenic by Nanofiltration," Desalination, Vol. 
117, No. 1-3, 1998, pp. 11-18. doi:10.1016/S0011-9164(98)00062-9

[12] Y. Sato, et al., "Performance of Nanofiltration for Arsenic Removal," Water Research, Vol. 36, No. 13, 2002, pp. 3371-3377. doi:10.1016/S0043-1354(02)00037-4

[13] M. A. Paul and R. L. Douglas, "Anisotropic Flat Sheet Membrane Formation via TIPS: Atmospheric Convection and Polymer Molecular Weight Effects," Journal of Membrane Science, Vol. 175, No. 2, 2000, pp. 225-238. doi:10.1016/S0376-7388(00)00422-1

[14] R. C. Leda, et al., "Influence of Matrix Activation and Polymer Coating on the Purification of Human $\lg G$ with Protein A Affinity Membranes," Journal of Membrane Science, Vol. 172, No. 1-2, 2000, pp. 269-277. doi:10.1016/S0376-7388(00)00343-4

[15] E. M. Vrijenhook and J. J. Waypa, "Arsenic Removal from Drinking Water by a Loose Nanofiltration Membrane," Desalination, Vol. 130, No. 3, 2000, pp. 265-277. doi:10.1016/S0011-9164(00)00091-6

[16] K. Kŏsutíc, et al., "Removal of Arsenic and Pesticides from Drinking Water by Nanofiltration Membranes," Separation and Purification Technology, Vol. 42, No. 2, 2005, pp. 137-144. doi:10.1016/j.seppur.2004.07.003

[17] C. M. Nguyen, et al., "Performance and Mechanism of Arsenic Removal from Water by a Nanofiltration Membrane," Desalination, Vol. 245, No. 1-3, 2009, pp. 82-94. doi:10.1016/j.desal.2008.04.047

[18] K. Boussu, et al., "Characterization of Polymeric Nanofiltration Membranes for Systematic Analysis of Mem- brane Performance," Journal of Membrane Science, Vol. 278, No. 1-2, 2006, pp. 418-427. doi:10.1016/j.memsci.2005.11.027

[19] M. Kang, et al., "Effect of pH on the Removal of Arsenic and Antimony Using Reverse Osmosis Membranes," Desalination, Vol. 131, No. 1-3, 2000, pp. 293-298. doi:10.1016/S0011-9164(00)90027-4

[20] M. Sen, et al., "Removal of Arsenic from Contaminated Groundwater by Membrane-Integrated Hybrid Treatment System," Journal of Membrane Science, Vol. 354, No. 1-2, 2010, pp. 108-113. doi:10.1016/j.memsci.2010.02.063

[21] S. Y. Thomas, et al., "Arsenic Toxicity, Health Hazards and Removal Techniques from Water: An Overview," Desalination, Vol. 217, No. 1-3, 2007, pp. 139-166. doi:10.1016/j.desal.2007.01.015

[22] M. Shin, "An Overview of Arsenic Removal by Pressure-Driven Membrane Processes," Desalination, Vol. 172, No. 1, 2005, pp. 85-97. doi:10.1016/j.desal.2004.07.031

[23] C. Bellona and J. E. Drewes, "The Role of Membrane Sufrace Charge and Solute Physico-Chemical Properties in the Rejection of Organic Acids by NF Membranes," Journal of Membrane Science, Vol. 249, No. 1-2, 2005, pp. 227-234. doi:10.1016/j.memsci.2004.09.041

[24] Y. N. Chen, et al., "Study of Arsenic(V) Adsorption on Bone Char from Aqueous Solution," Journal of Hazardous Materials, Vol. 160, No. 1, 2008, pp. 168-172. doi:10.1016/j.jhazmat.2008.02.120 